UDC 581.133.1:58.02

\title{
REALIZATION OF PROTECTIVE AND SYMBIOTIC PROPERTIES OF SOYBEANS USING FUNGICIDE SEED TREATMENT
}

\author{
T. P. Mamenko ${ }^{1 *}$, S. Ya. Kots ${ }^{1}$, V. P. Patyka ${ }^{2}$ \\ ${ }^{1}$ Institute of Plant Physiology and Genetics, the NAS of Ukraine \\ 31/17, Vasylkivska Str., Kyiv, Ukraine, 03022 \\ ${ }^{2}$ D. K. Zabolotny Institute of Microbiology and Virology, the NAS of Ukraine, \\ 154, Acad. Zabolotnoho Str., Kyiv, Ukraine, 03143
}

E-mail:t_mamenko@ukr.net

Received March 31, 2021 / Received June 22, 2021 / Accepted July 19, 2021

\begin{abstract}
Aim. The elaboration of efficient legume-rhizobial symbiosis systems, involving active strains of nodule bacteria, in the combination with fungicide seed treatment may be an alternative method of providing ecologically friendly nitrogen sources to plants and promoting their tolerance to the external factors, which is relevant for preservation and restoration of environmental quality. Therefore, the aim of our study was to determine the impact of pre-sowing seed treatment with fungicides, which differ in the action spectrum of active substances - Standak Top (fipronil, $250 \mathrm{~g} / 1$, thiophanate-methyl, $225 \mathrm{~g} / \mathrm{l}$, pyraclostrobin, $25 \mathrm{~g} / \mathrm{l}$ ) and Maxim XL (fludioxonyl, $25 \mathrm{~g} / \mathrm{l}$, metalaxyl, $10 \mathrm{~g} / \mathrm{l}$ ), on the intensity of the development of lipid peroxidation processes, the activity of antioxidant enzyme ascorbate peroxidase and nitrogen fixation activity in soybeans on the early stages of forming legume-rhizobial symbiosis. Methods. Microbiological (cultivation of a bacterial culture, seed inoculation), physiological (vegetative experiment), biochemical (spectrophotometric determination of the content of lipid peroxidation products and the activity of ascorbate peroxidase; measuring the nitrogen-fixation activity using a gas chromatography). Results. It was found that pre-sowing fungicide treatment of soybean seeds and subsequent inoculation with active rhizobia of strain $634 \mathrm{~b}$ did not result in the change in the content of TBA-active products in roots and root nodules (the values of indices were within the experiment deviation). At the same time, after seed inoculation using rhizobia and treatment with Maxim XL, there was an increase in the activity of ascorbate peroxidase in the roots from 20.3 to $30.8 \%$, and with Standak Top - from 20.0 to $29.8 \%$ during the early stages of ontogenesis till the formation of the third ternate leaf. Here, the activity of the enzyme in root nodules increased by $24.7-40.3 \%$ at the fungicidal effect. Our data demonstrate that the combination of fungicide seed treatment and inoculation with active rhizobia does not induce lipid peroxidation processes, but promotes the initiation of protective antioxidant properties in soybeans. It is accompanied with efficient functioning of the symbiotic apparatus, which is manifested in the increase in nitrogen-fixing activity of nodule bacteria, formed by active rhizobia of strain 634b after the seed treatment with Standak Top - by 98.3 and $78.1 \%$ and after Maxim XL - by 78.6 and $196.2 \%$ respectively, during the stages of the second and third ternate leaves. Conclusions. The pre-sowing soybean seed treatment with fungicides Standak Top and Maxim XL and the subsequent inoculation with active rhizobia of strain 634b does not induce the development of lipid peroxidation processes, but increases the activity of the antioxidant enzyme, ascorbate peroxidase, in the roots and root nodules, which is accompanied with the efficient work of the symbiotic apparatus on the early stages of determining legume-rhizobial symbiosis. This method of seed treatment may be a novel measure, to use in the technologies of cultivating soybeans to enhance the realization of the symbiotic potential and meet the needs of plants in ecologically friendly nitrogen, and to promote the formation of their tolerance to the corresponding cultivation conditions.
\end{abstract}

Key words: Glycine max (L.) Merr, Bradyrhizobium japonicum, TBA-active substances, ascorbate peroxidase, nitrogen fixation, nodulation, symbiotic system, fungicide.

DOI: https://doi.org/10.15407/agrisp8.02.024

\section{INTRODUCTION}

One of current strategic tasks of agriculture is to improve environmental and sustainable land manage-

(C) T. P. MAMENKO, S. Ya. KOTS, V. P. PATYKA, 2021 ment. The process of biological fixation of molecular nitrogen by microorganismsis the only natural source of providing plants with nitrogen, not impairing the environmental ecology. The formation of legume-rhizobial symbiotic systems, involving active strains of 
nodule bacteria, in combination with fungicide seed treatment is an important measure to enhance the efficiency of fixing ecologically pure nitrogen by plants and simultaneously increase their tolerance to the effect of biotic factors.

Solving the issue of a shift in balance in the plantpathogen-environment system and protection of plants from plant pathogenic microorganisms is one of the most important components in technologies of cultivating crops, including legumes (Kobak et al, 2016). In this aspect, there should be an integrated system of protecting crops depending on their phytosanitary state with harmonious combination of all the modern methods: organizational-economic, agrotechnical, immunologic, biologic, and chemical ones (Tribel and Strigun, 2011). At the same time, one of the main problems of plant protection is not just the application of chemical methods to protect plants, but rather the search for the ways to decrease the level of their harmfulness for environment (Petrichenko and Kots, 2014; Mamenko et al, 2019; Mamenko et al, 2020).

The plants of the family Fabaceae in the symbiosis with nodule bacteria (Rhizobiaceae) form an active symbiotic apparatus, and a combination of all the measures, aimed at the optimization of this process, promotes the realization of their nitrogen-fixation potential (Joshi et al, 2014). At present, there are active studies on the possibility of using seed inoculation with nodule bacteria prior the planting to regulate the metabolism of legumes and enhance their tolerance to biotic effects (Dicheng et al, 2018; Standish et al, 2018; AlonsoMonge et al, 2020; Laktionov et al, 2020; Rathjen et al, 2020; Getachew et al, 2021; Martinez et al, 2021; Santos et el, 2021).

During the formation of legume-rhizobial symbiosis, there is enhanced generation of reactive oxygen species (ROS), formed in the process of protective reactions of a host plant in response to the effect of external factors, including infection with microorganisms (Wang et al, 2018). ROS in plants are mainly formed during the processes of breathing, photosynthesis, and fixation of molecular nitrogen. The decisive role in maintaining the balance in production and scavenging of ROS in plant cells is simultaneously played by two systems of the plant organism - the antioxidant system to eliminate their excess and the signaling one, ensuring the initiation of protection mechanisms (Laxa et al, 2019; Noctor et al, 2018). A key enzyme in the antioxidant protection of cells, playing a relevant role in regulating ROS levels in plants under the effect of various external factors is ascorbate peroxidase (APO) (EC 1.11.1.11). APO is involved in cross-transduction pathways along with other antioxidant enzymes, eliminating ROS excess and stabilizing the internal biochemical state of a cell under stress factors, which leads to the tolerance of plants (Asthir et al, 2020).

A relevant role in perceiving ROS signals is played by cellular membranes with most starting enzymatic systems, involved in the initiation of calcium, lipoxygenase, phosphatide-oxalate signaling systems (Ayala et al, 2014). Therefore, there are no doubts concerning the participation of lipid peroxidation (LP) processes in the regulation of the system, supporting the homeostasis of plant cells, including the restoration of microbeplant interactions.

Soybean is the main leguminous crop in agriculture of both Ukraine and globally. At the same time, this crop is very sensitive to cultivation conditions and during the vegetation period is affected by many disease agents, which may lead to 15-30\% loss of grain, the decrease in protein content by $4-5 \%$, and 3-7 \% decrease in fat (Kobak et al, 2016).

The fungicides with different action spectra of active substances were selected for the study. Standak Top contains such chemical substances as fipronil, $250 \mathrm{~g} / 1$, thiophanate-methyl, $225 \mathrm{~g} / 1$, pyraclostrobin, $25 \mathrm{~g} / \mathrm{l}$, with combined fungicidal and insecticidal effect. The effect of fipronil lies in blocking gammaaminobutyric acid, which regulates the passing of a nervous impulse through chloride channels in the membranes of nervous cells of insects. Pyraclostrobin inhibits the mitochondrial respiration, blocking electron transfer and impairment of energy metabolism in the cells of a pathogen. Thiophanate-methyl inhibits the formation of ergosterol and the biosynthesis of nucleic acids in the cells of fungi (https://www.agro. basf.ru/ru/Products/Overview/).

Maxim XL contains two active substances - fluodioxonil, $25 \mathrm{~g} / \mathrm{l}$, metalaxyl, $10 \mathrm{~g} / \mathrm{l})$. Fluodioxonil is the analogue of a natural antibiotic, released by soil bacteria Pseudomonas pyrocinia. The mechanism of action of this preparation is related to the processes, inducing the impairment of transporting functions of membranes in the cells of a disease agent, thus inhibiting the growth and reproduction of the pathogen (https:// www.syngenta.ua/product/crop-protection/).

Active virulent Bradyrhizobium japonicum, strain $634 \mathrm{~b}$, are used in bacterial preparations for soybeans to enhance the efficiency of fixing molecular atmospheric nitrogen by root nodules (Novikova et al, 1984). 
The determination of the specificities in the formation of protective properties of legumes in the symbiosis with nodule bacteria strains using seed dressers is relevant for the search for efficient symbiotic systems, which would maximally realize their nitrogen-fixation potential and have enhanced adaptation ability.

The aim of the study was to investigate the impact of pre-sowing treatment of seeds, using fungicides Standak Top and Maxim XL, on the development of lipid peroxidation processes, the activity of antioxidant enzyme ascorbate peroxidase and nitrogen fixation activity in soybeans on early stages of the formation of legume-rhizobial symbiosis to find the possibility of using this treatment method to enhance protective and symbiotic properties of plants.

\section{MATERIALS AND METHODS}

The studies were conducted under controlled vegetation conditions using soybeans plants (Glycine max (L.) Merr.) of Almaz variety - an early ripening variety, recommended for cultivation in the Forest-Steppe of Ukraine, obtained by hybridization of a Moldavian line 3/86 and a Swedish variety Fiskeby 840-5-3 at the Poltava State Agrarian Academy (Biliavska, 2007).

The work was done using strains Bradyrhizobium japonicum 634b (active, virulent) (Novikova et al, 1984) and $604 \mathrm{k}$ (inactive, highly virulent) (Tolkachev et al, 1995) of different efficiency from the museum collection of nitrogen-fixing microorganisms from the Department of symbiotic nitrogen-fixation at the Institute of Plant Physiology and Genetics, the NAS of Ukraine. Inactive highly virulent strain B. japonicum $604 \mathrm{k}$ is a mutant, isolated from the nodule while passaging strain $604 \mathrm{k}$ through soybeans plants in the high radiation area - "cesium spot" which lost its ability of effective symbiosis (Tolkachev et al, 1995). Active virulent strain $B$. japonicum $634 \mathrm{~b}$ was isolated from the soybean nodule by analytic selection (Novikova et al, 1984).

Prior to sowing, the soybean seeds were treated with the solutions of fungicides Maxim XL 035 PS (Syngenta, Switzerland) and Standak Top (BASF, Germany), according to the application rate for one dose of each preparation, indicated by the manufacturer per one ton of seeds - Standak Top (10 1/t), Maxim XL (1 1/t). One part of seeds, treated with fungicide, was inoculated with the suspension of rhizobia for one hour. The culture of slow-growing nodule bacteria was cultivated on mannitol-yeast medium for 9 days at $26-28{ }^{\circ} \mathrm{C}$ (the titer of bacteria was $10^{8}$ cells in $1 \mathrm{ml}$ ). The inoculation titre was 200-300 thousand cells of rhizobia per one seed. Another part of the seeds, treated with fungicides, was not subjected to inoculation with rhizobia. The control was the variants without bacterization and fungicidal treatment of seeds and with inoculation using rhizobia (364b and 604k) without fungicides.

The plants were cultivated in pots on sandy medium with the addition of Herligel nutrient solution $(0.25$ nitrogen norm) (Grodzinskii, 1973) under natural illumination and optimal water supply. To conduct the studies, the roots of soybeans were extracted in early stages of ontogenesis - primordial leaves (VC), the first ternate leaf (V1), the second (V2) and third (V3) ternate leaves as well as root nodules during the stage of the third ternate leaf (V3). There were 12 pots per one variant, 6 plants per pot.

Biological nitrogen fixation (BNF) was measured using the gas chromatograph "Agilent GC system 6850" (USA) with the flame ionization detector (Hardy, 1968 ) at the core facility of multiple access to devices/ equipment "Gas Chromatography-Mass-Spectrometry" of the Institute of Plant Physiology and Genetics, the NAS of Ukraine. Gas separation was performed at the column (Supelco Porapak N) at the thermostat temperature of $55{ }^{\circ} \mathrm{C}$ and the detector $-150{ }^{\circ} \mathrm{C}$. Helium was a carrier gas ( $20 \mathrm{ml}$ per 1 minute). The volume of the gas mixture sample under analysis was $1 \mathrm{cc}$. Pure ethylene was used as a standard (Sigma-Aldrich, No. 536164, USA) (https://www.sigmaaldrich.com/UA/en/ product/aldrich/536164).

The total activity of BNF was presented in molar units of the ethylene obtained $\left(\mu \mathrm{mol} \mathrm{C}_{2} \mathrm{H}_{4}\right)$ per plant per one hour. The value of its specific quantity was calculated per unit of mass of root nodules from one plant and presented in molar units of ethylene obtained in one hour ( $\mu \mathrm{mol} \mathrm{C}_{2} \mathrm{H}_{4} / \mathrm{h}$ nodules $\left.\cdot h\right)$.

To determine the activity of the antioxidant enzyme APO, the weighed quantity of plant material was homogenized with cooled $60 \mathrm{mM}$ phosphate buffer $(\mathrm{pH}$ 7.5 ) in the 1:2 ratio (mass/volume), containing $2 \mathrm{mM}$ EDTA, $1 \mathrm{mM}$ PMSF, $5 \mathrm{mM} \beta$-mercaptoethanol and $1 \%$ polyvinylpyrrolidone. The homogenate was centrifuged at $10,000 \mathrm{rpm}$ for $20 \mathrm{~min}$ at $4{ }^{\circ} \mathrm{C}$. The supernatant was used to determine APO activity. The reaction mixture contained: $60 \mathrm{mM}$ potassium-phosphate buffer (pH 7.0), $0.1 \mathrm{mM}$ EDTA, $0.2 \mathrm{mM}$ ascorbate, $0.1 \mathrm{mM}$ hydrogen peroxide. The reaction was initiated with $100 \mu \mathrm{l}$ supernatant. APO activity was measured by the decrease in optic density at the wavelength of 290 $\mathrm{nm}$ for $2 \mathrm{~min}$ due to the oxidation of ascorbate $(\varepsilon=$ $=2.8 \mathrm{mM}^{-1} \mathrm{~cm}^{-1}$ ) using the scanning double-beam spectrophotometer UV-1900 (Shimadzu, Japan) (Na- 
kano and Asada, 1981). The results were presented in $\mu \mathrm{mol}$ of the oxidated ascorbate calculated as per the content (mg) of the total soluble protein per one minute, which was defined according to Bradford (Bradford, 1976).

The intensity of the course of LP processes was estimated by the content of TBA-active products, determined as a result of color reaction with thiobarbituric acid (TBA). To obtain the plant extract, the samples $(0.5 \mathrm{~g})$ were homogenized with $3 \mathrm{ml}$ of distilled water. Then $3 \mathrm{ml}$ of trichloracetic acid was added to sample and homogenized again. Two samples, $2 \mathrm{ml}$ each, were extracted from each homogenate. $2 \mathrm{ml}$ trichloracetic acid was added to one of them and used as a control on the spectrophotometer. $2 \mathrm{ml}$ of TBA solution was added to the other (experimental) sample. The samples were incubated for $30 \mathrm{~min}$ on water bath, cooled, and centrifuged at 3,000 rpm for $10 \mathrm{~min}$. The supernatant liquid was carefully taken by a syringe into tubes and measured on the spectrophotometer at $\lambda=532 \mathrm{~nm}$. The value of non-specific absorption was calculated at $\lambda=600 \mathrm{~nm}$. The results were presented as calculated per number of nmol malondialdehyde (MDA) in a gram of wet weight using a molar coefficient of extinction $1.55 \times 105 \mathrm{~cm}^{-1} \cdot \mathrm{M}^{-1}$ (Heath and Paker, 1968). The nitrogen fixation activity was determined in 10 repeats, and the biochemical parameters (TBA-active products and APO) - in 6 repeats.

Figures 1-3 and Table 1 present the arithmetic means and their standard deviations $(\mathrm{x} \pm \mathrm{SE})$. The significance of differences between the samplings was evaluated by ANOVA method, using U-criterion of Mann-Whitney. The differences were deemed reliable at $\mathrm{P}<0.05$.

\section{RESULTS}

It was determined that the treatment of soybean seeds with fungicide Standak Top led to the increase in the content of TBA-active products in the roots by $16.1 \%$ during the stage of primordial leaves as compared to the concentration of these substances in the soybean roots in the variant without seed treatment (Fig. 1,a). During this stage of ontogenesis, no differences were found in the course of LP in the soybean roots between the experiment variants with seed treatment using Maxim XL and without such treatment. During the stage of the first ternate leaf, there was intense development of LP in the soybean roots at the effect of Standak Top which is manifested in the increase in the content of TBA-active products by $53.2 \%$ as compared with the concentration of these substances in the soybean roots in the variant without seed treatment, whereas at the effect of Maxim XL the content of TBA-active products increased by $14.8 \%$ in the roots. No development of LP was determined during the subsequent stages of ontogenesis until the formation of the third ternate leaf at the effect of both fungicides, since the level of TBA-active products in the roots was within the experiment deviation.

The inoculation of soybean seeds with inactive, highly virulent rhizobia of strain $604 \mathrm{k}$ led to the decrease in the content of TBA-active products in the roots by $16.1 \%$ during the stage of primordial leaves and the increase in their concentration in the roots during the stage of the first ternate leaf by $27.2 \%$ as compared with the non-inoculated plants (see Fig. 1, $a, b$ ). During the following stage of ontogenesis until the formation of the third ternate leaf, the intensity of LP in the soybean roots in the symbiosis with inactive rhizobia remained practically on the same level.

Soybean seed treatment with Maxim XL in combination with rhizobia of inactive strain $604 \mathrm{k}$ did not induce significant changes in the LP in the roots during the stages of primordial leaves and the first ternate leaf as compared with the inoculated plants without fungicides (Fig. 1, b). During the stages of the second and third ternate leaves, there was a decrease in the development of these processes in the roots by $17.3-17.6 \%$ after seed treatment with Maxim XL and inoculation with inactive rhizobia of strain $604 \mathrm{k}$.

In case of using Standak Top for pre-sowing seed treatment and inoculation with rhizobia of the inactive strain $604 \mathrm{k}$, there was a decrease in the intensity of LP in the roots in early stages of ontogenesis (Fig. 1,b). When Standak Top was used for seed treatment during the stage of primordial leaves, there was a decrease by $25.8 \%$ in the content of lipid peroxidation products in the soybean roots, inoculated with inactive rhizobia, as compared with the concentration of TBAactive products in the roots of inoculated plants without fungicides. During the phase of the first ternate leaf and prior to the formation of the third ternate leaf there was a decrease in the level of lipid peroxidation products by $20.0 \%$ in the soybean roots after seed treatment with Maxim XL and inoculation with inactive rhizobia.

After the inoculation of soybeans with active soybean rhizobia, there was a considerable decrease in the development of LP in the roots during the stage of primordial leaves as compared with the inoculated plants (by $38.3 \%$ ) and inoculated inactive rhizobia (by $26.5 \%$ ) (see Fig. 1, $a, b, c$ ). During the subsequent stages of ontogenesis until the formation of the third 
MAMENKO et al.

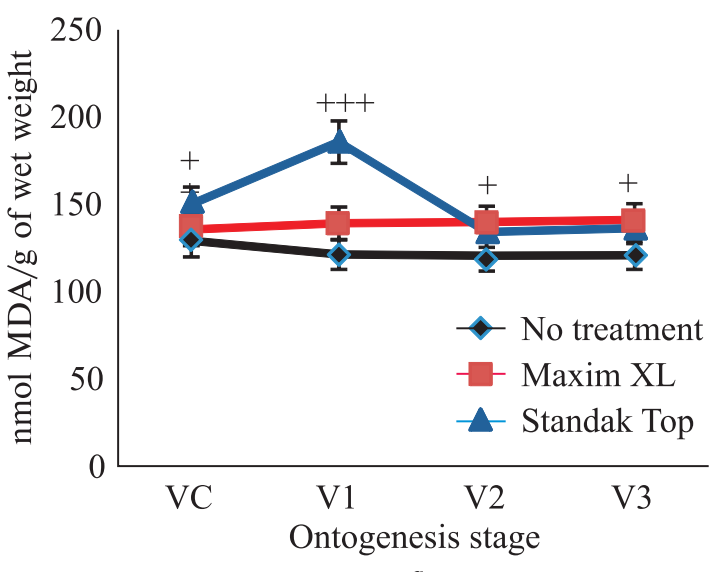

$a$

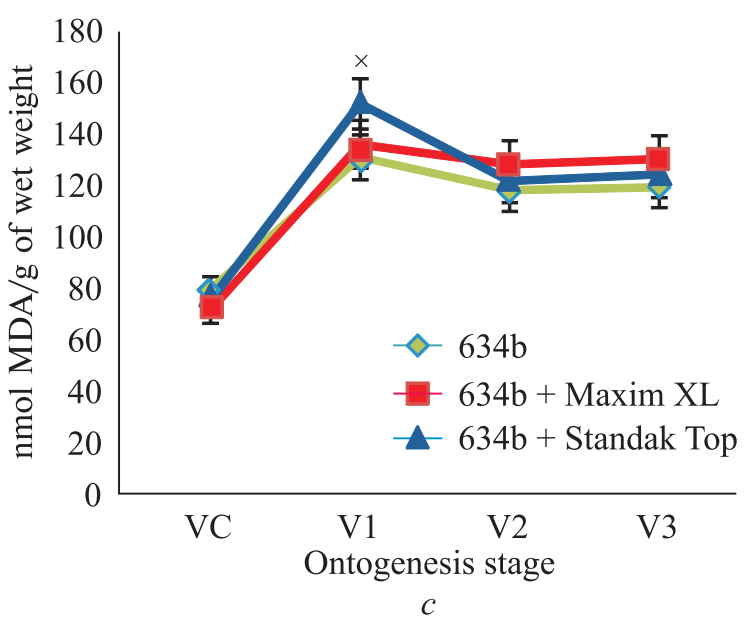

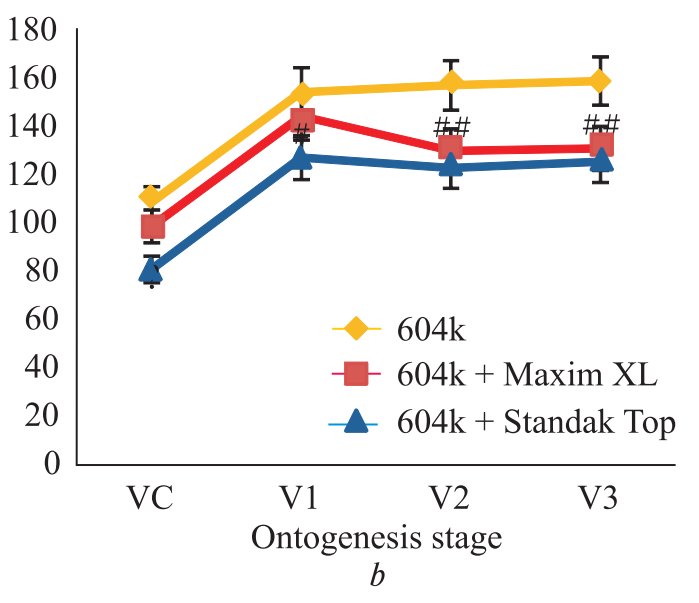

Fig. 1. The impact of fungicide seed treatment on the content of TBA-active products in the roots of soybeans, non-inoculated with rhizobia $(a)$ and inoculated with inactive $(b)$, active (c) strains of B. japonicum in early stages of ontogenesis: VC - primordial leaves, V1 first ternate leaf, V2 - second ternate leaf, V3 - third ternate leaf. $(x \pm S E, n=6)$; the data as compared with the control are reliable at ${ }^{+\neq \times}-\mathrm{P}<0.05 ;^{++\# \times x}-\mathrm{P}<0.01 ;^{+++\# \times \times x}-$ $\mathrm{P}<0.001\left(^{+}-\right.$regarding the variant without the fungicide treatment; $\neq \mathrm{i}^{\times}$- regarding variants with the inoculation using strains $604 \mathrm{k}$ and $634 \mathrm{~b}$, respectively) ternate leaf, the rate of these processes in soybeans roots in the symbiosis with active rhizobia was lower as compared with their development in the inactive symbiotic system.

The variants with pre-sowing treatment of soybean seeds using fungicides Maxim XL and Standak Top and subsequent inoculation with rhizobia of the active strain $634 \mathrm{~b}$ did not demonstrate considerable differences during LP in the roots in early stage of growth and development of plants as compared with inoculated plants without seed dressers (Fig. 1, c).

The treatment of soybean seeds with fungicides without bacterization induced the increase in APO activity in the roots in early stages of ontogenesis till the formation of the third ternate leaf from 30 to $40 \%$ at the effect of Standak Top and from 40 to $50 \%$ at the effect of Maxim XL (Fig. 2,a).

After the inoculation of soybean seeds with rhizobia of inactive highly virulent strain $604 \mathrm{k}$, there was an increased activity of APO in the soybean roots by $31.7 \%$ during the stage of primordial leaves and by $24.0 \%$ during the stage of the first ternate leaf as com- pared with non-inoculated plants. During the following stages of ontogenesis until the formation of the third ternate leaf, the activity of the enzyme in the roots of soybean plants, inoculated with inactive rhizobia, remained practically on the same level (Fig. 2, b).

The pre-sowing treatment of soybean seeds with fungicides and inoculation with inactive rhizobia did not demonstrate significant changes in the activity of the enzyme in the soybean roots as compared with the inoculated plants without the application of fungicides during the stage of primordial leaves. During the stage of the first ternate leaf, the activity of the enzyme increased in the roots of these plants by 26.3 and $16.8 \%$ respectively, after the application of Standak Top and Maxim XL. During the following stages of ontogenesis, the activity of the enzyme in the roots gradually increased and reached its maximal level of activity in the stage of the third ternate leaf which was $51.2 \%$ (Standak Top) and $37.5 \%$ (Maxim XL) higher than in the inoculated plants without the fungicides.

After the inoculation of soybean seeds with the active virulent strain of rhizobia $634 \mathrm{~b}$, there was an increase 

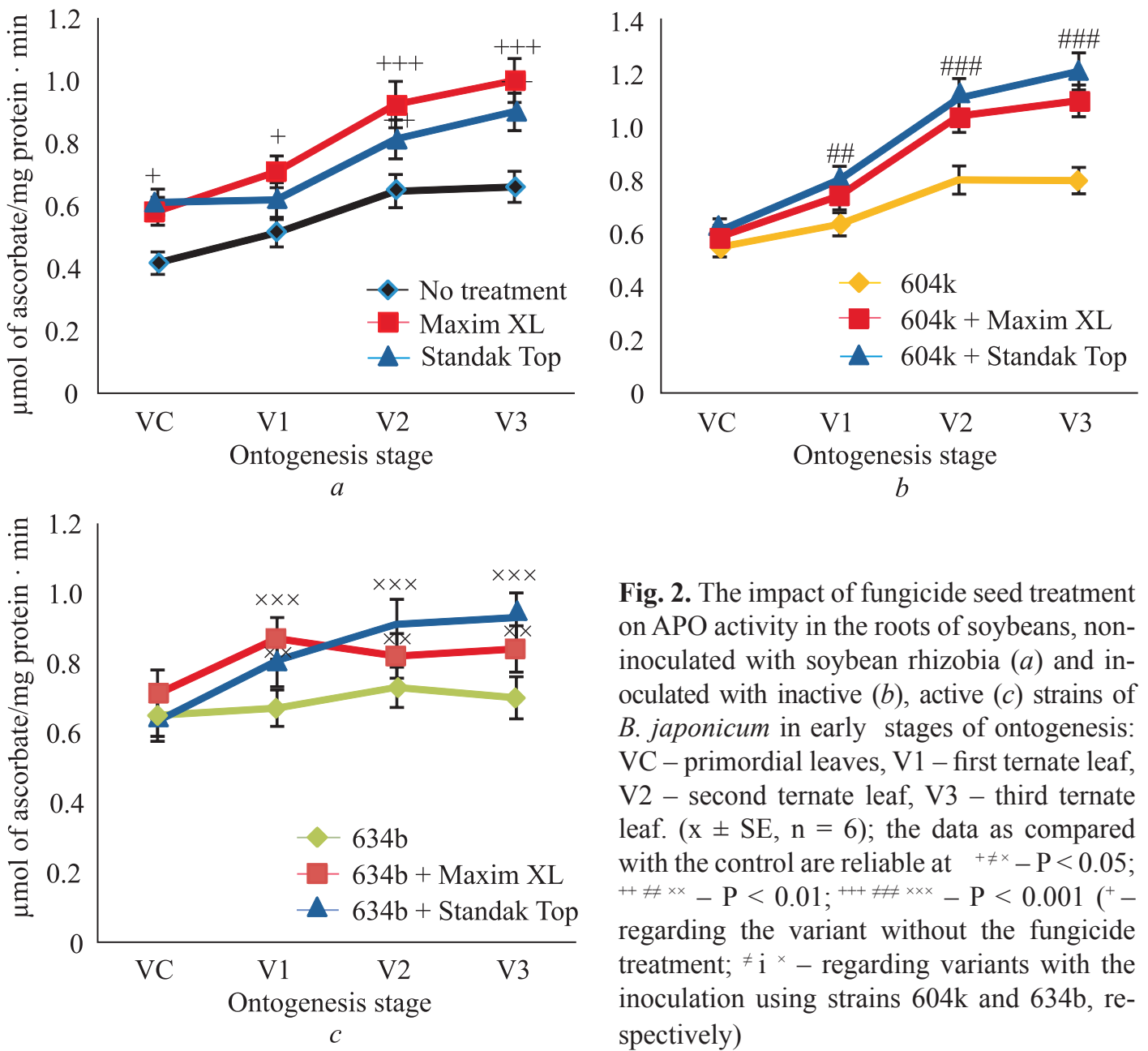

Fig. 2. The impact of fungicide seed treatment on APO activity in the roots of soybeans, noninoculated with soybean rhizobia $(a)$ and inoculated with inactive $(b)$, active $(c)$ strains of B. japonicum in early stages of ontogenesis: $\mathrm{VC}$ - primordial leaves, V1 - first ternate leaf, $\mathrm{V} 2$ - second ternate leaf, V3 - third ternate leaf. $(\mathrm{x} \pm \mathrm{SE}, \mathrm{n}=6)$; the data as compared with the control are reliable at ${ }^{+\neq \times}-\mathrm{P}<0.05$; $+\# \times x-\mathrm{P}<0.01 ;++\ldots \times x \times-\mathrm{P}<0.001\left(^{+}-\right.$ regarding the variant without the fungicide treatment; $\neq \mathrm{i}^{\times}$- regarding variants with the inoculation using strains $604 \mathrm{k}$ and $634 \mathrm{~b}$, respectively)

in APO activity in the soybean roots during the stage of the primordial leaf and the first ternate leaf by 56.2 and $30.8 \%$ respectively as compared with the inoculated plants (Fig. 2,c). During the following stages of ontogenesis until the formation of the third ternate leaf, the

activity of the enzyme in the roots of these plants was at the level of the non-inoculated ones. No significant differences were found in the level of APO activity in the soybeans roots in the active symbiotic system as compared with the inactive symbiosis.

The impact of fungicide seed treatment on the intensity of LP and APO activity in soybean root nodules, formed by B. japonicum strains of different efficiency. Stage of the third ternate leaf $(\mathrm{x} \pm \mathrm{SE}, \mathrm{n}=6)$

\begin{tabular}{l|c|c}
\hline \multicolumn{1}{c|}{ Variant } & $\begin{array}{c}\text { TBA-active products, } \\
\text { nmol MDA/g of wet weight }\end{array}$ & $\begin{array}{c}\text { Ascorbate peroxidase, } \mu \text { mol } \\
\text { of ascorbate/mg of protein } \cdot \min \end{array}$ \\
\hline Strain 604k & $222.45 \pm 15.25$ & $0.621 \pm 0.051$ \\
Standak Top + strain 604k & $281.22 \pm 19.14^{\#}$ & $0.674 \pm 0.044$ \\
Maxim XL + strain 604k & $236.74 \pm 16.11$ & $0.533 \pm 0.032^{\#}$ \\
Strain 634b & $104.02 \pm 7.18$ & $0.186 \pm 0.012$ \\
Standak Top + strain 634b & $116.83 \pm 8.11$ & $0.261 \pm 0.018^{\times \times}$ \\
Maxim XL + strain 634b & $106.73 \pm 9.12$ & $0.232 \pm 0.016^{\text {xx }}$ \\
\hline
\end{tabular}

Note: the data as compared with the control are reliable at ${ }^{\neq \times}-\mathrm{P}<0.05 ; \# \times x-\mathrm{P}<0.01 ;{ }^{\# \neq \times x}-\mathrm{P}<0.001\left({ }^{\neq} \mathrm{i}^{\times}-\right.$regarding the variants with the inoculation with strains $604 \mathrm{k}$ and $634 \mathrm{~b}$, respectively). Soybeans, the seeds of which had not been inoculated with rhizobia, did not form root nodules. 
The treatment of soybean seeds with fungicides and the inoculation with active rhizobia did not induce reliable changes in APO activity in the roots in the stage of primordial leaves as compared with the inoculated plants without fungicides. During the stage of the first ternate leaf, the activity of the enzyme increased in the roots of these plants by $29.8 \%$ at the effect of Standak Top and by $20.3 \%$ at the effect of Maxim XL. During the stage of the second and third ternate leaves, the activity of the enzyme in the soybean roots increased by 12.3 and $20.0 \%$, respectively, at the effect of Standak Top, while after Maxim XL these values amounted to 24.6 and $32.8 \%$, respectively.

During the stage of the third ternate leaf, the content of TBA-active products in the soybean root nodules, formed by inactive rhizobia of strain 604k, was 2.1 times higher than in soybean root nodules in the symbiosis with active rhizobia of strain $634 \mathrm{~b}$ (Table).

After soybean seed treatment with Standak Top in the inefficient symbiotic system, there was a $26.4 \%$ increase in the concentration of lipid peroxidation products in the soybean root nodules in the stage of the third ternate leaf. However, after the effect of Standak Top in the efficient symbiotic system no reliable increase in the content of TBA-active products was registered in the soybean root nodules as compared with the inoculated soybeans plants without the application of fungicides.

The seed treatment with Maxim XL did not demonstrate any significant differences in the accumulation of lipid peroxidation products in the soybeans root nodules in both symbiotic systems, formed with the involvement of different strains of rhizobia.

During the stage of the third ternate leaf, APO activity in the soybean root nodules, formed by inactive rhizobia, exceeded the level of enzyme activity in the soybean roots nodules, inoculated with active rhizobia, 3.3 times (Table).

The fungicide seed treatment and the inoculation with inactive rhizobia of strain $604 \mathrm{k}$ did not lead to significant changes in APO activity in the soybean root nodules, whereas after the fungicide seed treatment and inoculation with active rhizobia of strain $634 \mathrm{~b}$, there was an increase in the enzyme activity in root nodules by $40.3 \%$ (Standak Top) and $24.7 \%$ (Maxim XL).

The pre-sowing treatment of soybean seeds with fungicides and inoculation with the rhizobia of active strain $634 \mathrm{~b}$ promotes enhanced fixation of molecular atmospheric nitrogen by root nodules of the soybeans (Fig. 3). During the stages of the second and third ternate leaves, at the effect of Standak Top the total BNF of root nodules increased 1.9 and 1.7 times respectively, whereas its specific value increased 1.9 and 1.2 times. In case of using Maxim XL to treat seeds, there was an 1.7 and 2.9 times increase in the total BNF of the root nodules, and its specific value increased 17 and 1.8 times during the phases of the second and third ternate leaves.

\section{DISCUSSION}

The symbiosis of legumes and nodule bacteria is one of the most efficient biological nitrogen fixation systems, which is of great ecologic and practical relevance (Patyka et al, 2015). And the targeted combination of all the measures, aimed at optimizing the symbiosis process, promotes the formation of a powerful symbiotic apparatus, improvement in the phytosanitary state of the fields, improvement in soil fertility and obtaining high yield of soybeans with the best quality indices (Mikolaevsky et al, 2017). The study of key mechanisms of symbiotic interaction regulation is required for possible management of this process with the purpose of enhancing the realization of nitrogen fixation potential and tolerance of legumes to the corresponding cultivation conditions.

Recent publications demonstrate active studies on the application of fungicidal preparations to regulate the metabolism of legumes in the symbiosis with nodule bacteria to increase their tolerance to biotic factors (Joshi et al, 2014; Dicheng et al, 2018; Standish et al, 2018). To conduct a more detailed analysis of the specificity of the course of physiological-biochemical processes during the formation of legume-rhizobial symbiosis at the fungicidal seed treatment, we used the symbiotic systems, formed by rhizobia strains with different activity and virulence.

The analysis of the results demonstrated that in both symbiotic systems, regardless of the activity and virulence of rhizobia strains, there was a decrease in the content of TBA-active products in soybean roots during the stage of primordial leaves. Their concentration in the soybean roots in the symbiosis with active rhizobia was lower as compared to inactive symbiosis. During the subsequent stages of ontogenesis prior to the formation of the third ternate leaf, there was an increase in PL intensity in soybean roots in both symbiotic systems. The level of development of these processes in the roots was higher in the inefficient symbiotic system than in the efficient one.

There was an increase in APO activity in soybean roots during the early stages of the growth and deve- 

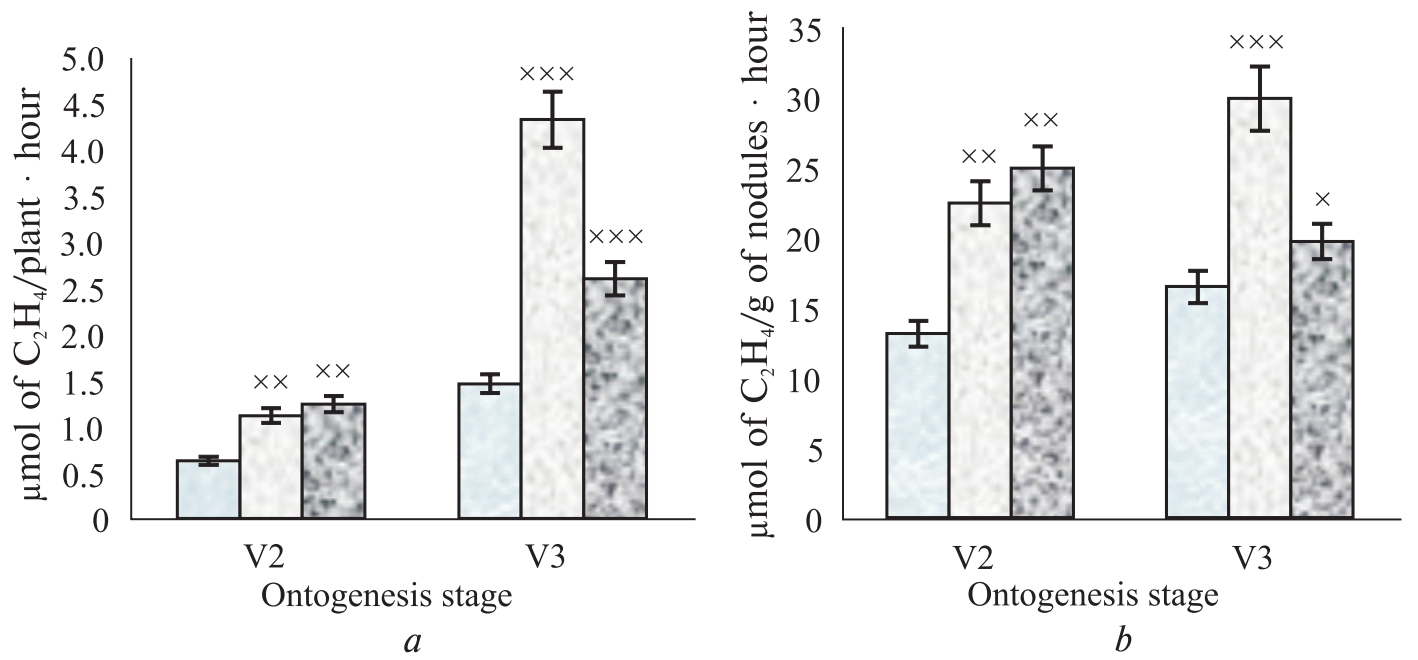

Fig. 3. The impact of soybeans seed treatment with fungicides and their inoculation with B. japonicum $634 \mathrm{~b}$ on the total $(a)$ and specific $(b)$ BNF activity of the root nodules during early stages of ontogenesis: V2 - the second ternate leaf, V3 - the third ternate leaf. $(\mathrm{x} \pm \mathrm{SE}, \mathrm{n}=6)$; the mean values of the indices for three years are presented; the data as compared with the control are reliable at ${ }^{\times}-\mathrm{P}<0.05$; ${ }^{\times x}-\mathrm{P}<0.01{ }^{\times \times x}-\mathrm{P}<0.001$ ( ${ }^{\times}$- as compared with the variant with the inoculation with strain $634 \mathrm{~b})$. No BNF was registered in the root nodules in the inefficient symbiotic system

lopment of plants, with the maximal level of activity during the stage of the third ternate leaf and practically no differences between both symbiotic systems.

The stage of primordial leaves is especially important for soybean plants in the symbiosis with nodule bacteria. During this period of ontogenesis, there is active formation of symbiotic structures - nodule primordia, which is accompanied with the restructuring in the cellular wall of the root (Gallego-Giraldo et al, 2014, Sulis et al, 2020) and, obviously, has relevant changes during the biochemical processes under investigation.

During the stages of the first and second ternate leaves, there is intense formation of nodules on soybean roots which fix molecular atmospheric nitrogen, although very poorly. During the stage of the third ternate leaf, the structure of root nodules is formed in such a way, that they are capable of active nitrogen fixation, which is ensured by the work of nitrogenase enzyme complex (Andrews, 2017; Wang et al, 2018).

We demonstrated that during the stage of the third ternate leaf, the accumulation of lipid peroxidation products in the soybean root nodules, formed by inactive rhizobia, was twice higher and the level of APO activity was three times higher than the level of the mentioned indices in the soybean root nodules, formed by active rhizobia. The observed changes in biochemical processes in the soybean root nodules, formed by inactive rhizobia, were conditioned by the fact that although the inefficient symbiotic system, formed with the involvement of inactive highly virulent rhizobia of strain $604 \mathrm{k}$, forms a great number of nodules on soybean roots, they still are not capable of realizing their nitrogen fixation function completely. It may induce the formation of stress-protective state of plants as a response to the insufficient provision for the needs of a plant in nitrogen, which is accompanied with changes in biochemical processes in root nodules, the increase in PL and the activity of antioxidant protection systems, including the antioxidant enzyme APO.

It is known that the accumulation of lipid peroxidation products in plants may demonstrate the transfer of cellular metabolism into the stressor state under the effect of external factors. At the same time, they may play a key role in forming stress-protective responses and supporting homeostasis of plant cells (Ayala et al, 2014). The balance between both parts of the prooxidant-antioxidant system - PL, on the one hand, and the antioxidant activity, on the other, is the requirement for normal life activity of the cell, including the formation of plant-microbial interactions (Laxa et al, 2014).

The researchers note that an important factor in protecting soybean plants from diseases and pests is fungicide seed treatment in the combination with the application of inoculants, based on microsymbionts Bradyrhizobium japonicum, which, in their turn, promote the increase in resistance to stress and productivity of plants (Joshi et al, 2014; Mikolaevsky et al, 2017) At the same time, some studies demonstrated that the prep- 
arations with fungicidal activity cause an impairment of the regulatory signaling system between macro- and microsymbionts, blocking of activity of nodulation genes, and a decrease in the level of rhizobial Nod-factor (Fox et al, 2007; Rathjen et al, 2020). In addition, each investigated chemical substance competitively limited the activation of gene Nod-factor depending on its concentration and inhibiting action (Bikrol et al, 2005).

Our studies demonstrated that the pre-sowing seed treatment with fungicides without bacterization leads to the increase in the intensity of PL processes and significant intensification of APO activity in the soybean roots during early stages of plant development. The fungicide seed treatment on the background of inoculation with inactive rhizobia induced a significant decrease in the development of LP in soybeans roots as compared with the inoculated plants without fungicides. The bacterization of seeds with active rhizobia and fungicide treatment induced the approximation of the intensity in the development of these processes in the roots to the level, equal to that of inoculated plants without fungicides. These data may suggest a positive impact of the fungicide seed treatment and inoculation with active rhizobia on preserving the integrity of cellular membranes (Sweeney et al, 2018a, 2018b).

When fungicides were applied in both symbiotic systems, no reliable changes were registered in the APO activity value in the soybean roots during the stage of primordial leaves and the first ternate leaf. During the stages of the second and third ternate leaves, the level of enzyme activity was higher in the soybean roots in the variants with the seed inoculation with inactive rhizobia and fungicide treatment, especially with Standak Top. We also registered an increase in the intensity of PL processes in soybean root nodules during the stage of the third ternate leaf in the inefficient symbiotic system after the application of Standak Top. No increase in APO activity was registered in soybean root nodules, formed by inactive rhizobia at the effect of both fungicides (the data are presented in Table).

Under the application of fungicides in the efficient symbiotic system, there was another tendency in the development of these processes - an insignificant accumulation of lipid peroxidation products and the increase in APO activity in the soybean root nodules during the stage of the third ternate leaf. In our opinion, this specific course of the mentioned biochemical processes in soybeans under the inoculation of the seeds with rhizobia and the treatment with fungicidal preparations was conditioned, first and foremost, by different symbiotic properties of the strain, their activity and virulence, and the formation of active and inactive nodules on the roots, as described above.

The indices of the formation and functioning of root nodules in legumes in the symbiosis with nodule bacteria are an integral component of evaluating the efficiency of their symbiotic apparatus. The combination of the results of such studies and some biochemical indices is important in determining the specificity of functioning of the formed symbiotic system, its ability to realize its symbiotic and adaptive potentials at the effect of additional factors, including the effect of fungicides.

We have been conducting studies on this aspect for the last three years (2019-2021). Our studies demonstrate this tendency in nodule-formation process in soybeans at the effect of fungicidal preparations, thus the results are not presented in this article. However, BNF indices of soybean root nodules were different in some years if the seeds were treated with the fungicides under investigation, which was described in the publications (Mamenko et al, 2019; Mamenko et al, 2020). For instance, in 2019 we registered a similar tendency in the effect of both fungicidal preparations, which was manifested in the BNF increase in the soybeans (Mamenko et al, 2019). In 2020, the seed treatment with Maxim XL demonstrated better indices of BNF of root nodules as compared with this index in soybeans under the application of Standak Top (Mamenko et al, 2020).

This article presents the generalization of three sets of annual data (including 2021). These data demonstrate that the application of fungicide Maxim XL for pre-sowing treatment of soybean seeds and inoculation with active rhizobia of strain $634 \mathrm{~b}$ promoted the increase in BNF of root nodules by $196.2 \%$ while after Standak Top this index increased by $78.1 \%$ during the stage of the third ternate leaf. Our results do not deny the positive effect of seed treatment with Standak Top, but suggest that both fungicidal preparations are efficient and increase BNF of soybeans when used in combination with active rhizobia. However, the selection of one of investigated fungicides should be conditioned by, first and foremost, the task of the researcher, considering different spectra of active substances in their composition. As previously mentioned, Standak Top contains chemical substances with fungicidal and insecticidal effect.

\section{CONCLUSIONS}

The pre-sowing seed treatment with fungicides Standak Top and Maxim XL and subsequent inoculation with active rhizobia of strain $634 \mathrm{~b}$ does not cause the 
development of LP processes but stimulates the activity of antioxidant enzyme APO in the roots (within 20.0 $30.8 \%$ ) and root nodules (by 24.7 and $40.3 \%$ ) which is accompanied with the increase in nitrogen fixation activity (by 78.1 and $196.2 \%$ ) in soybeans on early stages of the legume-rhizobial symbiosis. This method of seed treatment may be used in modern technologies of soybeans cultivation to provide for the needs of plants in ecologically pure nitrogen and to enhance the realization of their protective antioxidant properties due to the stimulation of the activity of antioxidant enzymes, which would promote the development of soybeans tolerance to the corresponding cultivation conditions.

Adherence to ethical principles. All experiments described in this paper were non animal based.

Conflict of interests. The authors declare the absence of any conflicts of interests.

Financing. This study was not financed by any specific grant from financing institutions in the state, commercial or non-commercial sectors.

\section{Реалізація захисних і симбіотичних властивостей у сої за обробки насіння фунгіцидами}

Т. П. Маменко ${ }^{1 *}$, С. Я. Коць ${ }^{1}$, В. П. Патика ${ }^{2}$

${ }^{1}$ Інститут фізіології рослин і генетики НАН України, Вул. Васильківська, 31/17, Київ, Україна, 03022

${ }^{2}$ Інститут мікробіології і вірусології ім. Д.К. Заболотного НАН України,

Вул. Академіка Заболотного, 154, Київ, Україна, 03143

$$
\text { e-mail: t_mamenko@ukr.net }
$$

Мета. Створення ефективних бобово-ризобіальних симбіотичних систем за участю активних штамів бульбочкових бактерій у поєднанні 3 обробкою насіння фунгіцидами може бути альтернативним шляхом для забезпечення рослин екологічно чистими джерелами азоту та сприятиме підвищенню їхньої толерантності до дії зовнішніх чинників, що має важливе значення для збереження і відтворення якості довкілля. У зв'язку з цим метою нашої роботи було з'ясувати вплив передпосівної обробки насіння фунгіцидами, які відрізняються за спектром дії діючих речовин - Стандак Топом (фіпроніл, 250 г/л, тіофанат-метил, 225 г/л, піраклостробін, 25 г/л) і Максимом XL (флудіоксоніл, 25 г/л, металаксил, 10 г/л) на інтенсивність розвитку процесів ліпопероксидації, активність антиоксидантного ензиму аскорбатпероксидази та азотфіксувальну активність у сої на ранніх етапах формування бобово-ризобіального симбіозу. Методи. Мікробіологічні (вирощування бактеріальної культури, інокуляція насіння), фізіологічні (вегетаційний експеримент), біохімічні (спектрофотометричне визначення вмісту про- дуктів ліпопероксидації та активності аскорбатпероксидази, а також вимірювання азотфіксувальної активності за допомогою газового хроматографа). Результати. Встановлено, що передпосівна обробка насіння сої фунгіцидами та наступна інокуляція активними ризобіями штаму 6346 не призводить до зміни вмісту ТБК-активних продуктів у коренях і кореневих бульбочках (значення показників у межах похибки досліду). Водночас за інокуляції насіння ризобіями та обробки Максимом XL зафіксовано підвищення активності аскорбатпероксидази у коренях від 20,3 до $30,8 \%$, а за використання Стандак Топу - від 20,0 до 29,8 \% впродовж ранніх фаз онтогенезу до формування третього трійчастого листка. При цьому активність ензиму у кореневих бульбочках підвищується на 24,7-40,3 \% за дії фунгіцидів. Отримані дані засвідчують, що використання обробки насіння фунгіцидними препаратами сумісно з інокуляцією активними ризобіями не індукує розвиток процесів ліпопероксидації, однак сприяє включенню захисних антиоксидантних властивостей у сої. Це супроводжується ефективним функціонуванням симбіотичного апарату, про що свідчить зростання азотфіксувальної активності кореневих бульбочок, утворених активними ризобіями штаму 6346 за обробки насіння Стандак Топом на 98,3 і 78,1 \%, а за використання Максиму XL на 78,6 і 196,2 \%, відповідно, у фази другого і третього трійчастого листків. Висновки. Передпосівна обробка насіння сої фунгіцидами Стандак Топом і Максимом XL та наступна інокуляція активними ризобіями штаму 6346 не спричиняє розвиток процесів ліпопероксидації та підвищує активність антиоксидантного ензиму аскорбатпероксидази у коренях і кореневих бульбочках, що супроводжується ефективною роботою симбіотичного апарату на ранніх етапах встановлення бобово-ризобіального симбіозу. Такий спосіб обробки насіння може бути сучасним заходом у технологіях вирощування сої для підвищення реалізації симбіотичного потенціалу та забезпечення потреб рослин в екологічно чистому азоті, а також сприятиме формуванню їх толерантності до відповідних умов вирощування.

Ключові слова: Glycine max (L.) Merr, Bradyrhizobium japonicum, ТБК-активні продукти, аскорбатпероксидаза, азотфіксація, нодуляція, симбіотична система, фунгіцид.

\section{REFERENCES}

Alonso-Monge R, Guirao-Abad JP, Sánchez-Fresneda R, Pla J, Yagüe G, Argüelles JC. (2020) The Fungicidal Action of Micafungin is Independent on Both Oxidative Stress Generation and HOG Pathway Signaling in Candida albicans. Microorganisms. 8(12):1867. doi: 10.3390/ microorganisms8121867.

Andrews M, Andrews ME. (2017) Specificity in legumerhizobia symbioses. Inter. J. Mol. Sci., 18(4), 1-39. doi: 10.3390/ijms 18040705 . 
Asthir B, Kaur G, Kaur B. (2020) Convergence of pathways towards ascorbate-glutathione for stress mitigation. J. Plant Biol. 63:243-257. doi: 10.1007/s12374-020-09253-7.

Ayala A, Muñoz MF, Argüelles S. (2014) Lipid peroxidation: production, metabolism and signaling mechanisms of malondialdehyde and 4-hydroxy-2-nonenal. Oxidat. Med. Cell. Longevity. 6:360-438. doi: 10.1155/2014/360438.

Bikrol A, Saxena N, Singh K. (2005) Response of Glycine $\max$ in relation to nitrogen fixation as influenced by fungicide seed treatment. Afr. J. Biotechnol. 4(7):667671. doi:10.5897/AJB2005.000-3122.

Biliavska LH. (2007) Soia Almaz. Kyiv, Ukraine. Patent No. 07105.http://dspace.pdaa.edu.ua:8080/handle/ 123456789/3526 (in Ukrainian).

Bradford MA. (1976) Rapid and sensitive method for the quantitation of the microgram quantities of protein utilizing: the principle of protein - dye binding. Analyt. Biochem.. 72:248-254.

Dicheng MD, Jiamei ZJ, He L, Cui K, Mu W, Liu F. (2018) Baseline sensitivity of Phytophthora capsici to the strobilurin fungicide benzothiostrobin and the efficacy of this fungicide. Europ. J. Plant Pathol. 152(3):723-733. doi: 10.1007/s10658-018-1514-8.

Fox JE., Gulledge J, Engelhaupt E, Burow ME, McLachlan $J A$. (2007) Pesticides reduce symbiotic efficiency of nitrogen-fixing rhizobia and host plants. Proceeding of the National Academy of Sciences of the USA. 104(24): 10282-10287. doi: 10.1073/pnas.0611710104.

Gallego-Giraldo L, Bhattarai K, Pislariu CI, Nakashima J, Jikumaru Y, Kamiya Y, Udvardi MK, Monteros MJ, Dixon RA. (2014) Lignin modification leads to increased nodule numbers in alfalfa. Plant Physiology. 164(3): 1139-50. doi:10.1104/pp.113.232421.

Getachew Z, Abeble L. (2021) Effect of seed treatment using Mancozeb and Ridomil fungicides on Rhizobium strain performance, nodulation and yield of soybean (Glycine $\max$ L.). Journal of Agriculture and Natural Resources. 4(2):86-97. doi:10.3126/janr.v4i2.33674.

Grodzinskii AM, Grozdzinskii DM. (1973) Kratkii spravochnik po fiziologii rastenii. Kyiv. Naukova dumka. $600 \mathrm{p}$ (in Ukrainian).

Hardy RWF, Holsten RD, Jackson EK, Burns RC. (1968) The acetylene-ethylene assay for nitrogen fixation: laboratory and field evaluation. Plant Physiology. 43(8):1185-1207. doi: 10.1104/pp.43.8.1185.

Heath R, Paker L. (1968) Photoperoxidation in isolated chloroplast. 1. Kinetics and stoichiometry of fatty acid peroxidation. Arch. Biochem. Biophys. 125(1): 189-198. doi: 10.1016/0003-9861(68)90654-1.

Joshi J, Sharma S, Guruprasad KN. (2014) Foliar application of pyraclostrobin fungicide enhances the growth, rhizobial-nodule formation and nitrogenase activity in soybean. Pestic Biochem Physiol. 114:61-66. doi: 10. 1016/j.pestbp.2014.07.002.

Kobak SI, Kolisnyk OV, Serevetnyk SI. (2016) The most common soybean diseases and the effectiveness of BASF drugs for their control. Agribusiness today. 10:46-47 (in Ukrainian).

Laktionov YV, Kosulnikov YV, Yachno VV, Kozhemyakov AP. (2020) Determination of toxicity of various preparative forms of pesticidal fungicides for nodule bacteria inoculants. E3S Web of Conferences. 224:04032. doi:10.1051/e3sconf/202022404032.

Laxa M, Liebthal M, Telman W, Chibani K, Dietz K-J. (2019) The role of the plant antioxidant system in drought tolerance. Antioxidants (Basel). 8(4):1-31. doi: 10.3390/ antiox8040094.

Mamenko TP, Khomenko YO, Kots SY. (2019) Influence of fungicides on activities of enzymes of phenolic metabolism in the early stages of formation and functioning of soybean symbiotic apparatus. Regulatory Mechanisms in Biosystems. 10(1):111-116. doi: 10.15421/021917.

Mamenko TP, Kots SY, Khomenko YO. (2020) The intensity of ethylene release by soybean plants under the influence of fungicides in the early stages of legume-rhizobial symbiosis. Regulatory Mechanisms in Biosystems. 11(1):98-104. doi: 10.15421/022014.

Martinez DA, Loening UE, Graham MC., Gathorne-Hardy A. (2021) When the Medicine Feeds the Problem; Do Nitrogen Fertilisers and Pesticides Enhance the $\mathrm{Nu}-$ tritional Quality of Crops for Their Pests and Pathogens? Front. Sustain. Food Syst. 12. doi: 10.3389/ fsufs.2021.701310.

Mikolaevsky V, Sirenko V, Titova L. (2017) Influence of purposive bacterization of seeds on disease development and soybean yield. Stiinta Agricola. 1:55-59.

Nakano Y, Asada K. (1981) Hydrogen peroxidase is scavenged by ascorbate-specific peroxidase in spinach chloroplasts. Plant Cell Physiol. 22(5):867-880. doi: 10.1093/ oxfordjournals.pcp.a076232.

Novikova AT, Beresteckij OA, Abhazova AA, Georgadze LI. (1984) Shtamm klubenkovykh bakterii Rhizobium japonicum 634b, ispolzuemyi dlia izgotovleniia bakterialnogo preparata Nitrogina pod soiu. Avtorskoe svidetelstvo SU 1034358 A (04.08.1984, biuleten No. 13) (in Russian).

Noctor G, Reichheld JP, Foyerd CH. (2018) ROS-related redox regulation and signaling in plants. Seminars in Cell \& Developmental Biology. 80:3-12. doi: 10.1016/j. semcdb.2017.07.013.

Patika VP, Hnatiuk TT, Buletsa NM, Kirilenko LV. (2015) Biological nitrogen in the agricultural system. Agriculture. 2:12-20 (in Ukrainian).

Petrichenko VF, Kots SYa. (2014) Symbiotic systems in modern agricultural production. Bulletin of the NAS of Ukraine. 3:57-66 (in Ukrainian).

Rathjen JR, Ryder MH, Riley IT, Lai TV, Denton MDJ. (2020) Impact of seed-applied pesticides on rhizobial survival and legume nodulation. Appl Microbiol. 129(2):389-99. doi: $10.1111 /$ jam.14602. 
Santos MS, Rodrigues TF, Nogueira MA, Hungria M. (2021) The Challenge of Combining High Yields with Environmentally Friendly Bioproducts: A Review on the Compatibility of Pesticides with Microbial Inoculants. Agronomy. 11:870. doi: 3390/agronomy11050870.

Standish JR, Brenneman TB, Stevenson KL. (2018) Dynamics of fungicide sensitivity in Venturia effuse and fungicide efficacy under field conditions. Plant Disease. 102(8):1606-1611. doi: 10.1094/PDIS-12-17-1989-RE.

Sulis DB, Wang JP. (2020) Regulation of lignin biosynthesis by post-translational protein modifications. Front Plant Sci. 11:914. doi: 10.3389/fpls.2020.00914.

Sweeney DC, Weaver JC, Davalos RV. (2018a) Characterization of cell membrane permeability in vitro, part I: transport behavior induced by single-pulse electric fields. Technology in Cancer Research \& Treatment. 17:1-15. doi: $10.1177 / 1533033818792491$.
Sweeney DC, Douglas TA, Davalos RV. (2018b) Characterization of cell membrane permeability in vitro, part II: computational model of electroporation-mediated membrane transport. Technology in Cancer Research \& Treatment. 17:1-13. doi: 10.1177/1533033818792490.

Tolkachev NZ, Dubovenko EK, Chechelnitskaya LN. (1995) Inactive strain of soybean nodule bacteria. $9^{\text {th }}$ Bach Colloquium on Nitrogen Fixation. Abstracts. report (Moscow, January 24-26, 1995). Pushchino: p. 28 (in Russian).

Tribel SO, Strigun OO. (2011) Phytosanitary status of soybean agrocenoses and integrated plant protection. Plant protection and quarantine. 57:224-247 (in Ukra-inian).

Wang Q, Liu J, Zhu H. (2018) Genetic and molecular mechanisms underlying symbiotic specificity in legume-rhizobium interactions. Front Plant Sci. 9:313. doi: 10.3389/ fpls.2018.00313. 